Portland State University

PDXScholar

6-16-2021

\title{
Higher Education for All Law Enforcement Officers
}

Johana Constantino Madrigal

Portland State University

Follow this and additional works at: https://pdxscholar.library.pdx.edu/honorstheses

Part of the Criminology and Criminal Justice Commons, Higher Education Commons, and the Law Enforcement and Corrections Commons

Let us know how access to this document benefits you.

\section{Recommended Citation}

Constantino Madrigal, Johana, "Higher Education for All Law Enforcement Officers" (2021). University Honors Theses. Paper 1078.

https://doi.org/10.15760/honors.1105

This Thesis is brought to you for free and open access. It has been accepted for inclusion in University Honors Theses by an authorized administrator of PDXScholar. Please contact us if we can make this document more accessible: pdxscholar@pdx.edu. 


\title{
Higher Education for All Law Enforcement Officers
}

\author{
By: Johana Constantino Madrigal
}

An Undergraduate honors thesis submitted in partial fulfillment of the

requirements for the degree of

Bachelor of Science

in

University Honors

and

Criminology \& Criminal Justice

Thesis Advisor

Curt Sobolewski

Portland State University

May 18, 2021 


\begin{abstract}
In this brief prospectus, the focus is on the many arguments for why it should be a requirement for all law enforcement officers to have a higher education background. Given light to recent events, the importance for more highly trained and educated officers has become more dire as people call for justice in an attempt to right the wrongs that have been done. The articles found all address the manner in which higher education can help with better judgement calls, analyze and respond to situations better, and the overall perception officers have, who have a form of higher education, on their own job. In addition, looking into statistical numbers of officers who have achieved higher education. Through information gathered from multiple sources along with listing the many benefits that higher education would bring the officers and law enforcement as a whole, this prospectus supports requiring higher education for all law enforcement officers.
\end{abstract}


Research Question

How can higher education benefit law enforcement officers and should it be required?

It is important to take into account what factors play into whether or not current officers decide to go to school and pursue higher education. The most common factors for nontraditional students or adult students are cost, program availability, faculty/teacher reputation and the convenience of courses being offered; meaning if the courses will fit into their schedule since many colleges offer main courses during the day time (Hall \& Lambert, 2007). Other factors that influence this decision is the distance from their home or work to the school or class location and whether or not childcare would be available. These factors heavily influenced mostly nontraditional students in their decision if they would be pursuing a higher education. Traditional students have similar influences but the factors that came first for them were location, prestige, and academic quality (Hall \& Lambert, 2007). For these factors not to be difficult obstacles for individuals to overcome, it is important for schools to take them into consideration to create schedules that can work with both types of students.

For police departments that focus more on community policing, the interest in having their employees get a higher education was much higher but under the condition that there be financial help available that could aid them achieve that. An issue within this field though is that higher education has been undermined; more so the necessity of a degree because many in the field do not see it as a tool that can help them with problem-solving or achieve better interactions (del Carmen et al., 2006). Many years ago, I interviewed a patrol officer who told me exactly that and it would be "better" to go straight to the academy and work up to the next position if that is 
what one wanted. There is a notion in many officers' minds today that what one learns in the field compared to what is learned in a classroom is not the same causing a cascade of issues such as what has been seen in recent years with systemic racism and biases woven into the criminal justice system. Every field of study has its complexities that can't be learned in the classroom, but through my research, I have found that attending college and/or a university does help officers be better problem solvers and sees a reduction of police-on-civilian conflict.

There is a need for proper funding and as mentioned before, many believe that what is taught in the classroom isn't nearly half of what will actually be learned in the field (Paterson, 2011). Cordner (2016) stated that due to a push towards hard policing and reform, higher education for officers was never able to fully take off as it no longer became the focus. As we can see today, that is still the case for the vast majority of officers in the field. Rather than focusing on offering officers the opportunity to attend college and get a degree, in the 1960's and 70's the National Advisory Commission on Higher Education for Police Officers (HEPO) decided that the way education was being brought to these officers was not sufficient and that the way criminal justice and policing was being conducted was acceptable, noting that "criminal justice had already become the prevailing model of police higher education" (Cordner, 2016). It wasn't until the 1970's did police departments begin hiring officers with degrees more often and between the years of 1990 and 2000 larger cities required new officers to have some college with a percentage growth being from 19 percent to 37 percent (del Carmen et al., 2006). Today, many in the criminal justice and law enforcement field believe that the job requires physical training and "book" knowledge isn't necessary. Though, research and studies indicate differently. 
Studies have shown that officers that attended and have higher education backgrounds have better attitudes and are less likely to abuse their power (Paoline III et al., 2015). They are also more open-minded, less likely to use force, and more culturally understanding (Paoline III et al., 2015). Officers coming into the workforce with college-level higher education backgrounds have shown that they provide new concepts on how to reform and shape policing differently as well as have better interactions with the public and increase police legitimacy (del Carmen et al., 2006). Studies also show that they are less likely to be involved in shootings. Referencing a study by McElvain and Kposowa (2008), Cody Telep cited their work in his own article which stated that officers who were college educated were less likely to be involved in shootings. He also included that

Officers with any college were less likely to use verbal force in citizen encounters compared to officers with a high school diploma. Only officers with a four-year degree were significantly less likely to use physical force. Similarly, Rydberg and Terrill (2010) found that officers with at least some college degrees were less likely to use force. (p. 398).

When the article was published, only one percent of police departments required a bachelor's degree for its officers (Telep, 2011). It was also argued that when someone is in college, they develop communication skills, which would help an officer know how to interact with people of different backgrounds. It also increases a person's morality by having them concentrate on how they are equally treating others and lowering the potential of them abusing their power (Telep, 2011). 
Rounding back to the topic of community policing, higher education for officers has been connected to officers being more creative in the manners that they handle situations (Rydberg \& Terrill, 2010). Society wants officers that are more than just policemen and women. It is expected that they should maintain the peace and know how to handle intense situations that involve critical decision making. Other career fields that require such critical thinking and decision-making skills and that also deal with other people's lives require higher education. There is a call for police education to be "rigorous, tough-minded, and extensive if policemen are to meet the demands placed on them" (Jagiello, 1971). Since officers need to make very important decisions especially those involving other people's lives, they need to have a higher educational background that matches their responsibilities. Once again, the work of McElvain and Kposowa (2008) was referenced in Rydberg and Terrill (2010) work which found that officers with a college degree were more than $41 \%$ less likely to discharge their firearms than officers with a high school diploma or some college but no degree. One last point that should be taken into consideration is that officers with some college exposure and 4-year degrees are significantly less likely to use force in an encounter compared to non-college-educated officers. (Rydberg \& Terrill, 2010). Moving forward, two ways to push officers to go for higher education and get a degree are to hire more college graduates and encourage current officers to get their degrees (Watson \& Robinson, 2003).

In conclusion, there should be more programs available for current officers to attend school as the benefits would be increasing their knowledge and skills more. Skills they would be gaining range from critical thinking, sociology to further criminology knowledge and skills that they can put into practice among other things. Making it a requirement now will help incoming 
officers, agency departments, and society as a whole. Policing is an occupation that does need change for it to serve the community better, and higher education is one resource that can help with that change. In today's climate, there is nothing that law enforcement can lose, and one step that they can do to show that they are committed to making the necessary changes will be having higher education become a requirement. 


\section{Work Cited}

Cordner, G. (2016). The Unfortunate Demise of Police Education. Journal of Criminal Justice Education, 27(4), 485-496.

https://doi-org.proxy.lib.pdx.edu/10.1080/10511253.2016.1190134

del Carmen, A., Butler, R., \& Odo, J. (2006). Criminology and Criminal Justice through the Lenses of the Law Enforcement Community: An Attitudinal Assessment. Criminal Justice Studies, 19(2), 209-222.

https://doi-org.proxy.lib.pdx.edu/10.1080/14786010600764583

Hall, D., Ventura, L., \& Lambert, E. (2007). Factors Influencing the Higher Education Decisions of Criminal Justice Professionals. American Journal of Criminal Justice, 32(1/2), 116-128. https://doi-org.proxy.lib.pdx.edu/10.1007/s12103-007-9003-1

Jagiello, R. J. (1971). College Education for the Patrolman -- Necessity or Irrelevance? Journal of Criminal Law, Criminology \& Police Science, 62(1), 114-121.

https://doi-org.proxy.lib.pdx.edu/10.2307/1142134

Paoline III, E. A., Terrill, W., \& Rossler, M. T. (2015). Higher Education, College Degree Major, and Police Occupational Attitudes. Journal of Criminal Justice Education, 26(1), 49-73. https://doi-org.proxy.lib.pdx.edu/10.1080/10511253.2014.923010

Paterson, C. (2011). Adding value? A review of the international literature on the role of higher education in police training and education. Police Practice \& Research, 12(4), 286-297. https://doi-org.proxy.lib.pdx.edu/10.1080/15614263.2011.563969

Rydberg, J., \& Terrill, W. (2010). The Effect of Higher Education on Police Behavior. Police Quarterly, 13(1), 92-120. https://doi.org/10.1177/1098611109357325

Telep, C. (2011). The Impact of Higher Education on Police Officer Attitudes toward Abuse of Authority. Journal of Criminal Justice Education, 22(3), 392-419. https://doi-org.proxy.lib.pdx.edu/10.1080/10511253.2010.519893

Watson, J., \& Robinson, E. (2003). Police Recruitment: The Way Forward. Police Journal, 76(1), 14-29. https://doi-org.proxy.lib.pdx.edu/10.1177/0032258X0307600103 